\title{
Nerve Growth Factor Receptors on Normal and Injured Sensory Neurons
}

\author{
V. M. K. Verge, ${ }^{1}$ R. J. Riopelle, ${ }^{2}$ and P. M. Richardson ${ }^{1}$ \\ ${ }^{1}$ Division of Neurosurgery, Montreal General Hospital and McGill University, Montreal, Canada, and ${ }^{2}$ Division of Neurology, \\ Queen's University, Kingston, Canada
}

The density and binding properties of receptors for nerve growth factor (NGF) in normal and injured sensory neurons have been analyzed by quantitative radioautography following incubation of tissue sections with radioiodinated NGF. The technique is designed to study binding sites that are half-maximally saturated by picomolar concentrations of NGF: Additional sites of lower affinity have not been emphasized. In normal adult rats, approximately half of lumbar sensory neurons have high-affinity receptors for NGF. One month after the sciatic nerve is cut, the mean number of high-affinity sites on heavily labeled neurons in the fifth lumbar dorsal root ganglion falls to less than $20 \%$ of normal values because of reduced receptor density and cell volume. Neurons with high-affinity receptors are more liable to atrophy after injury than those lacking such receptors. Receptors are lost not only in the cell bodies of sensory neurons but also on their peripheral and central processes. Delayed administration of NGF to the sciatic nerve 3 weeks after it is cut restores the receptor density to normal values and partially restores the neuronal cell volume.

As part of the response to axonal injury and possibly because the cell body is deprived of NGF, fewer high-affinity receptors are displayed by sensory neurons. For at least 3 weeks after nerve transection, neurons that are atrophic and depleted of NGF receptors can be resuscitated by exogenous NGF.

Nerve growth factor (NGF) is selectively internalized by some primary sensory neurons in adult mammals and influences their survival and function (Goedert et al., 1981; Richardson et al., 1984; E. M. Johnson et al., 1986). High-affinity receptors, halfmaximally saturated by picomolar concentrations of NGF, are thought to internalize NGF and mediate its biological actions (Sutter et al., 1979). More abundant low-affinity binding sites of uncertain biological importance are also found on many neurons with high-affinity NGF receptors. The relationship between 2 receptors of different affinity is not as well understood for NGF (Hosang and Shooter, 1985; Green and Greene, 1986) as for some other growth factors (Robb and Greene, 1987). Because of this ambiguity, studies with monoclonal antibodies to the

\footnotetext{
Received Mar. 15, 1988; revised Aug. 2, 1988; accepted Aug. 16, 1988

This work was supported by the Medical Research Council of Canada and the Canadian Paraplegic Association.

Correspondence should be addressed to Dr. P. M. Richardson, Division of Neurosurgery, Montreal General Hospital, 1650 Cedar Avenue, Montreal H3G 1A4, Canada.

Copyright (C) 1989 Society for Neuroscience $0270-6474 / 89 / 030914-09 \$ 02.00 / 0$
}

low-affinity receptor (Chandler et al., 1984; Ross et al., 1984; Taniuchi et al., 1988) or probes for the encoding mRNA (D. Johnson et al., 1986; Heuer et al., 1987; Radeke et al., 1987) cannot be assumed to apply to the high-affinity receptor. However, high-affinity NGF binding sites can be unequivocally identified and quantified by receptor radioautography on tissue sections (Richardson et al., 1986, 1988; Raivich and Kreutzberg, 1987).

The retrograde changes in nerve cell bodies following peripheral nerve injury can be broadly classified as degenerative or regenerative. The latter category is exemplified by an activated growth state which is demonstrable in both peripheral and central axons of sensory neurons following peripheral axotomy (McQuarrie et al., 1977; Richardson and Issa, 1984; Richardson and Verge, 1987). Degenerative neuronal reactions include atrophy and death (Aldskogius et al., 1985) plus decreased synthesis of several proteins (Rotter et al., 1977; Tessler et al., 1985; Hoffman et al., 1987). To explore the possible implication of NGF in neuronal responses to injury, high-affinity NGF receptors in sensory neurons were examined by quantitative receptor radioautography. Two specific questions were asked. First, does the number and/or affinity of receptors increase or decrease after peripheral nerve injury to correlate respectively with axonal regeneration or neuronal degeneration? Second, are changes in the NGF receptor, like some other reactions in injured sensory neurons (Fitzgerald et al., 1985; Rich et al., 1987), counteracted by exogenous NGF?

\section{Materials and Methods}

Surgical techniques. All experiments were performed on adult female Sprague-Dawley rats weighing approximately $200 \mathrm{gm}$. Before nerve cutting, nerve injection, or perfusion, the rats were anesthetized by intraperitoneal injection of pentobarbital $(50 \mu \mathrm{g} / \mathrm{gm})$. The standard procedure for 53 rats was to cut the right sciatic nerve, including the branch to biceps femoris, and to leave the left sciatic nerve intact. In 3 of these rats, the sciatic nerve was re-exposed 3 weeks after cutting, and NGF was infused to the nerve stump via silicone tubing attached to an osmotic pump (Alza). NGF was infused at $250 \mathrm{ng} / \mathrm{hr}(1 \mu \mathrm{l} / \mathrm{hr})$ in 0.1 м PBS containing BSA $(1 \mathrm{mg} / \mathrm{ml})$ and penicillin $(100 \mathrm{U} / \mathrm{ml})$. Rats were killed for radioautography $9 \mathrm{~d}$ after the pumps were inserted.

Preparation of NGF and ${ }^{125} I-N G F, \beta-N G F$ was purified from male mouse submandibular glands by cation-exchange chromatography (Mobley et al., 1976; Chapman et al., 1981) and radioiodinated by the lactoperoxidase method (Sutter et al., 1979), with final separation of radioligand from free iodine and lactoperoxidase (Richardson et al., 1988) on a cartridge (Accell CM, Waters). ${ }^{125}$ I-NGF with a specific activity of $80-200 \mu \mathrm{Ci} / \mu \mathrm{g}$ was usually used within $24 \mathrm{hr}$ of preparation.

Radioautographic studies. One to eight weeks after right sciatic nerve transection, rats were perfused with cold $0.1 \mathrm{M}$ PBS, $\mathrm{pH} 7.4$, and the fifth lumbar dorsal root ganglia (L5 DRG) were removed and quickly frozen in isopentane. Sections 6-10 $\mu \mathrm{m}$ thick were thaw-mounted on 
gelatin-coated slides and stored $1-3 \mathrm{~d}$ at $-80^{\circ} \mathrm{C}$. They were then incubated for $90 \mathrm{~min}$ at $20^{\circ} \mathrm{C}$ with $20-40$ pM ${ }^{125} \mathrm{I}-\mathrm{NGF}$ in $0.1 \mathrm{M}$ PBS, pH 7.4 , with magnesium chloride $(0.5 \mathrm{~mm})$, cytochrome $\mathrm{C}(1 \mathrm{mg} / \mathrm{ml})$, leupeptin $(4 \mu \mathrm{g} / \mathrm{ml})$, and phenylmethylsulfonylfluoride $(0.5 \mathrm{mM})$ (Richardson et al., 1986). For studies of the concentration dependence of binding, unlabeled NGF was added at $0-2560$ pm concentration. Following incubation with ${ }^{125} \mathrm{I}-\mathrm{NGF}$, the sections were rinsed for $3 \mathrm{~min}$ in several changes of cold PBS, fixed by immersion for $10 \mathrm{~min}$ in $4 \%$ paraformaldehyde, rinsed briefly in distilled water, and dried with cool filtered air. In earlier experiments, the sections were further fixed the next day in hot paraformaldehyde vapor for $2 \mathrm{hr}$ at $80^{\circ} \mathrm{C}$. In later experiments, fixative containing $2 \%$ paraformaldehyde and $2 \%$ glutaraldehyde was substituted for $4 \%$ paraformaldehyde, and the treatment with hot paraformaldehyde vapor was omitted. Sections were defatted, dipped in radioscnsitive cmulsion (Kodak NTB2), cxposcd at $4^{\circ} \mathrm{C}$ in lightproof boxes for 1-6 d, developed, and counterstained with thionin. Radioautographic standards, prepared from sections of brain homogenates with known amounts of ${ }^{125} \mathrm{I}-\mathrm{NGF}$, were fixed, defatted, dipped, exposed, and developed in the same way.

For quantification of radioautographic results, slides were examined by light microscopy under oil immersion (Fig. 1), and digitized images from a charge-coupled device were analyzed interactively by computer with software developed by W. G. Tatton (Playfair Neurosciences Unit, Toronto). Only neurons with visible nucleoli were selected for quantification. The cross-sectional area and fraction $(f)$ of area covered by grains were recorded and the correction $f /(1-f)$ was applied to yield a parameter linearly related to grain count (Richardson et al., 1988). Absolute amounts of ${ }^{125}$ I-NGF bound to tissue $(\mathrm{fmol} / \mathrm{mg}$ ) were obtained by comparison with the radioautographic standards on the assumption that the specific density of neurons is $1 \mathrm{gm} / \mathrm{cc}$. Diameters and volumes were calculated on the assumption that neurons are spherical. All radioautographs were examined without knowledge of laterality or concentration of radioligand. Scatchard plots were fitted to the expectations of 2 binding sites by an iterative program to minimize least squares (Minneman et al., 1979). Histograms of labeling densities were fitted to 2 normal curves by a maximum likelihood program (Lawson, 1979).

For 2 rats killed 7 weeks after transection of the right sciatic nerve, radioautographs were prepared from tranverse sections of the spinal cord through the entry zone of the $\mathbf{L} 5$ roots.

Neuronal counts. The number of neurons in the right and left L5 DRG was estimated in 4 rats with right sciatic nerve transection 4 weeks previously. In these animals, the nerve to the biceps femoris was spared. The rats were perfused with $4 \%$ paraformaldehyde, and cryostat sections, $20 \mu \mathrm{m}$ thick, were cut serially through the L5 DRG and stained with thionin. All neurons with visible nucleoli were counted in every fifth section, and the error due to split nucleoli was ignored.

Retrograde transport studies. In 13 rats, the right sciatic nerve was crushed in midthigh and the left nerve was intact. Both sciatic nerves were injected at the level of the crush site with a micropipette containing $11 \mathrm{ng}{ }^{125} \mathrm{I}-\mathrm{NGF}$ in $1 \mu \mathrm{l}$ saline either 0,4 , or $12 \mathrm{~d}$ after crush. Rats were killed $12 \mathrm{hr}$ after injection, and accumulation of gamma emission activity in L4 and L5 DRG was measured.

In 33 rats, the right sciatic nerve was cut in midthigh, and, 9-10 d later, $1 \mu \mathrm{l}$ of a solution containing $1.5-12 \mathrm{ng}$ of ${ }^{125} \mathrm{I}-\mathrm{NGF}$ was injected by micropipette into each sciatic nerve at the level of the nerve to the biceps femoris. Accumulation of gamma emission activity in L4 and L5 DRG was measured $18 \mathrm{hr}$ later following death. The data were fitted to a hyperbola (Barlow, 1983) to estimate the uptake capacity.

\section{Results}

\section{Receptor radioautography for normal $D R G$}

Two types of quantitative information were extracted from the radioautographs. Binding properties were analyzed for heavily labeled neurons at several concentrations of ${ }^{125} \mathrm{I}-\mathrm{NGF}$, and variation among neurons in labeling density was surveyed for a single concentration.

To study binding properties, radioautographs were prepared from adjacent sections of DRG incubated with 20 pM ${ }^{125}$ I-NGF and 0-2560 pM unlabeled NGF. At each concentration, neurons were selected from the most heavily labeled $10 \%$ and the concentration of bound NGF (radiolabeled plus unlabeled) was calculated. In 2 such analyses, Scatchard plots indicated het- erogeneous binding with 2 sites half-maximally saturated at picomolar $(23,49)$ or nanomolar concentrations (Fig. 2). The binding capacity for the high-affinity receptor was approximately $15 \mathrm{fmol} / \mathrm{mg}$ or $2-300,000$ receptors per medium-sized neuron. Low-affinity binding was not analyzed in detail. At the concentrations of ${ }^{125} \mathrm{I}-\mathrm{NGF}$ used for routine radioautography, high-affinity binding constitutes approximately half of the specific binding to heavily labeled neurons.

The concentration dependence of binding to the most lightly labeled neurons was examined in radioautographs of sections incubated with several concentrations of ${ }^{125}$ I-NGF (data not shown). At most concentrations, specific binding to these lightly labeled neurons was approximately $1 / 10$ that to heavily labeled neurons in the same section. By Scatchard plotting, no highaftinity receptors were detected on this subpopulation of neurons, and the density of low-affinity sites was relatively low. Because the dissociation-equilibrium constant for this scanty binding cannot be reliably determined, it remains unclear whether lightly labeled neurons possess true low-affinity receptors.

To examine labeling for a representative sample of neurons, random sections were selected from several simultaneously processed radioautographs of L5 DRG. Cross-sectional areas and corrected grain densities were recorded for all neurons with visible nucleoli with special effort to detect inconspicuous, small, lightly labeled neurons. In such radioautographs, nonspecific binding over non-neuronal areas of the ganglia was approximately $1 \mathrm{fmol} / \mathrm{mg}$, and specific binding over neurons ranged from 0 to 20 times background levels. No strong correlation between cell diameter and labeling was detected (Fig. 3). Histograms of labeling densities could be fitted to 2 normal curves designated as "labeled" and "unlabeled" populations (Fig. 4). Because the 2 populations overlap in labeling density, not all individual neurons could be classified as "labeled" or "unlabeled." In 3 analyses of normal ganglia ([ $\left.{ }^{25} \mathrm{I}-\mathrm{NGF}\right]=20-40 \mathrm{pM}$, $n=245-448$ neurons), the "labeled" populations were estimated to contain 43,60 , and $65 \%$ of all neurons and to have mean densities of specific labeling 5.7, 5.4, and 4.2 times background. Corresponding densities of specific labeling for the "unlabeled" population were $1.1,1.1$, and 0.5 times background.

\section{Changes in radioautographs following sciatic nerve transection}

Four weeks after transection of the right sciatic nerve, the numbers of neurons in L5 DRG on the left and right were estimated to be $5406 \pm 462$ and $4333 \pm 402$, respectively (mean \pm SEM, $n=4$ ). The mean ratio of counts in right and left DRG was $0.80 \pm 0.01$. These numbers were used to convert percentages to absolute numbers in the histograms of labeling density (Fig. 3). In receptor radioautographs for $\mathbf{4 8}$ pairs of ganglia examined 1-8 weeks after unilateral sciatic nerve injury, the binding of ${ }^{125}$ I-NGF was consistently diminished on the side of the cut nerve (Fig. 1). Quantitative data were obtained for 19 pairs of ganglia. For concentrations of $20-40$ pM ${ }^{125}$ I-NGF in the incubation medium and time intervals of 3-6 weeks after cutting, mean specific binding was significantly reduced to $58-88 \%$ of normal values. Small, medium, and large neurons were all subnormally labeled, and the absolute number of small lightly labeled neurons was above normal (Fig. 3). In histograms of labeling densities (Fig. 4, middle column), the mean density for the "labeled" population was reduced by one-third, whereas that for the "unlabeled" population was unchanged.

The change in density of high-affinity receptors is best appreciated in Scatchard plots because labeling at a single con- 


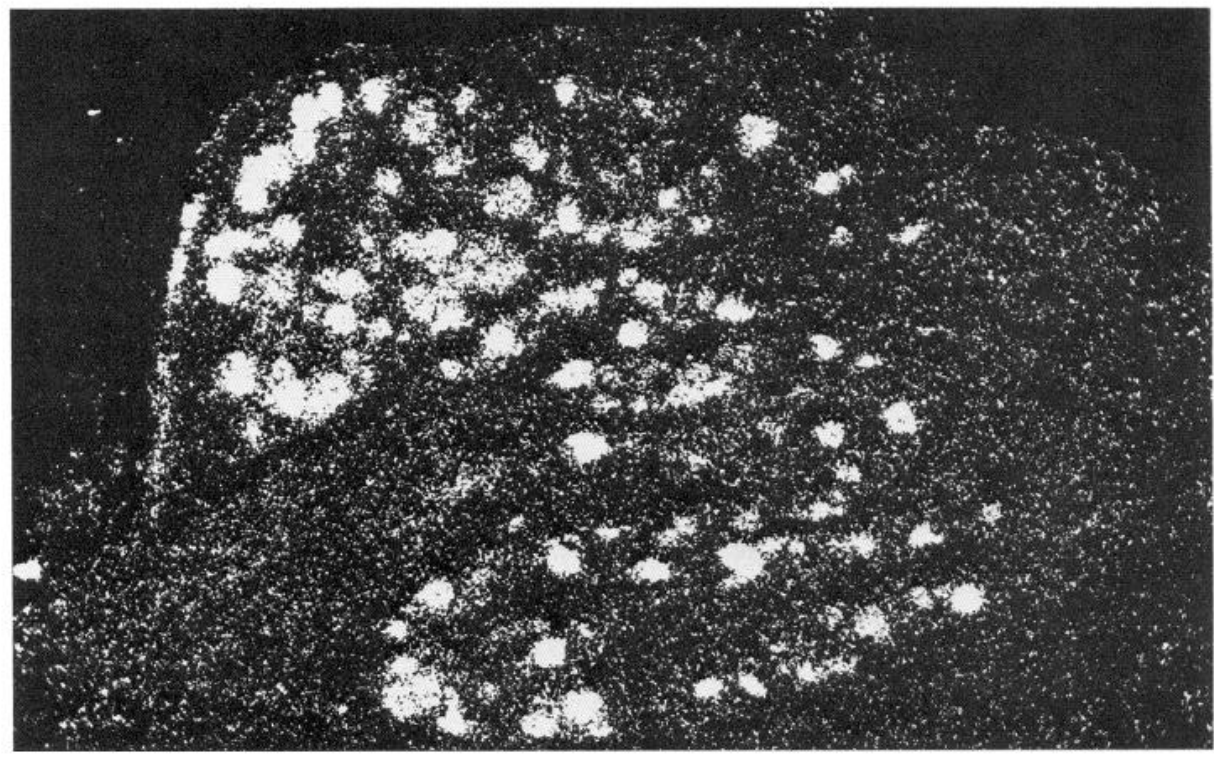

Figure 1. Photomicrographs of sections of L5 DRG incubated with ${ }^{125}$ INGF and prepared for radioautography. Top, Dark-field photograph of normal DRG (40 pM $\left.{ }^{125} \mathrm{I}-\mathrm{NGF}\right) . \times 75$. Middle, Dark-field photograph of the contralateral DRG associated with sciatic nerve transection 3 weeks earlier. The reduction in binding results from a decreased receptor density plus marked atrophy of neurons with many receptors $\left(40\right.$ pM ${ }^{125}$ I-NGF). $\times 75$. Bottom, Oil-immersion photograph showing 2 neurons in a normal DRG $(20 \mathrm{pM}$ ${ }^{125}$ I-NGF). $\times 1100$.
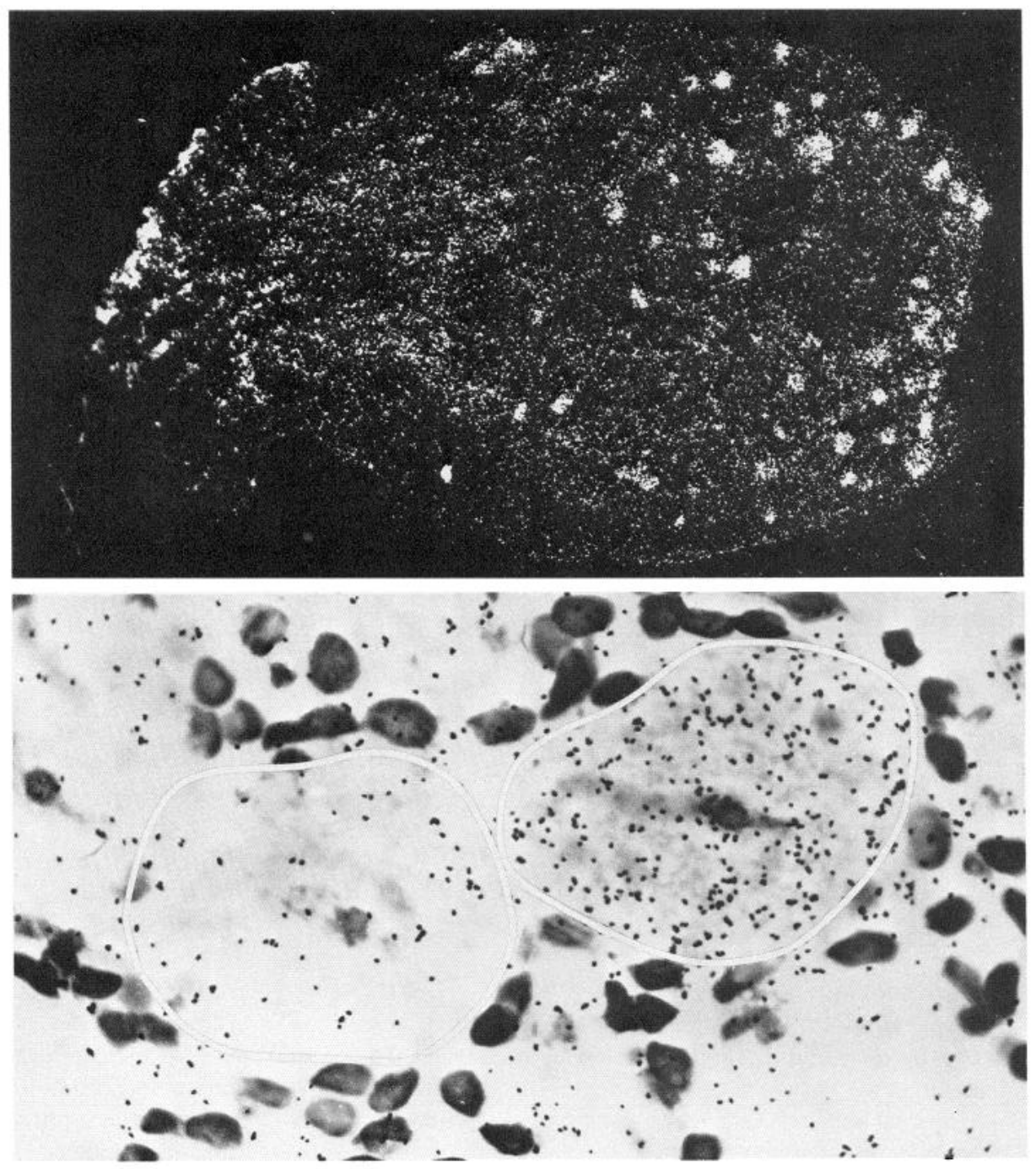

centration reflects a mixture of low- and high-affinity binding. By Scatchard analysis, the most heavily labeled $10 \%$ of neurons were still seen to have 2 binding sites after injury (Fig. 3). Highaffinity binding was reduced to one-third of normal; low-affinity and nonspecific binding were apparently unchanged.

Reduction in perikaryal size after peripheral nerve transection was also quantified (Table 1). For all time intervals, atrophy was more severe for the most heavily labeled third of neurons 

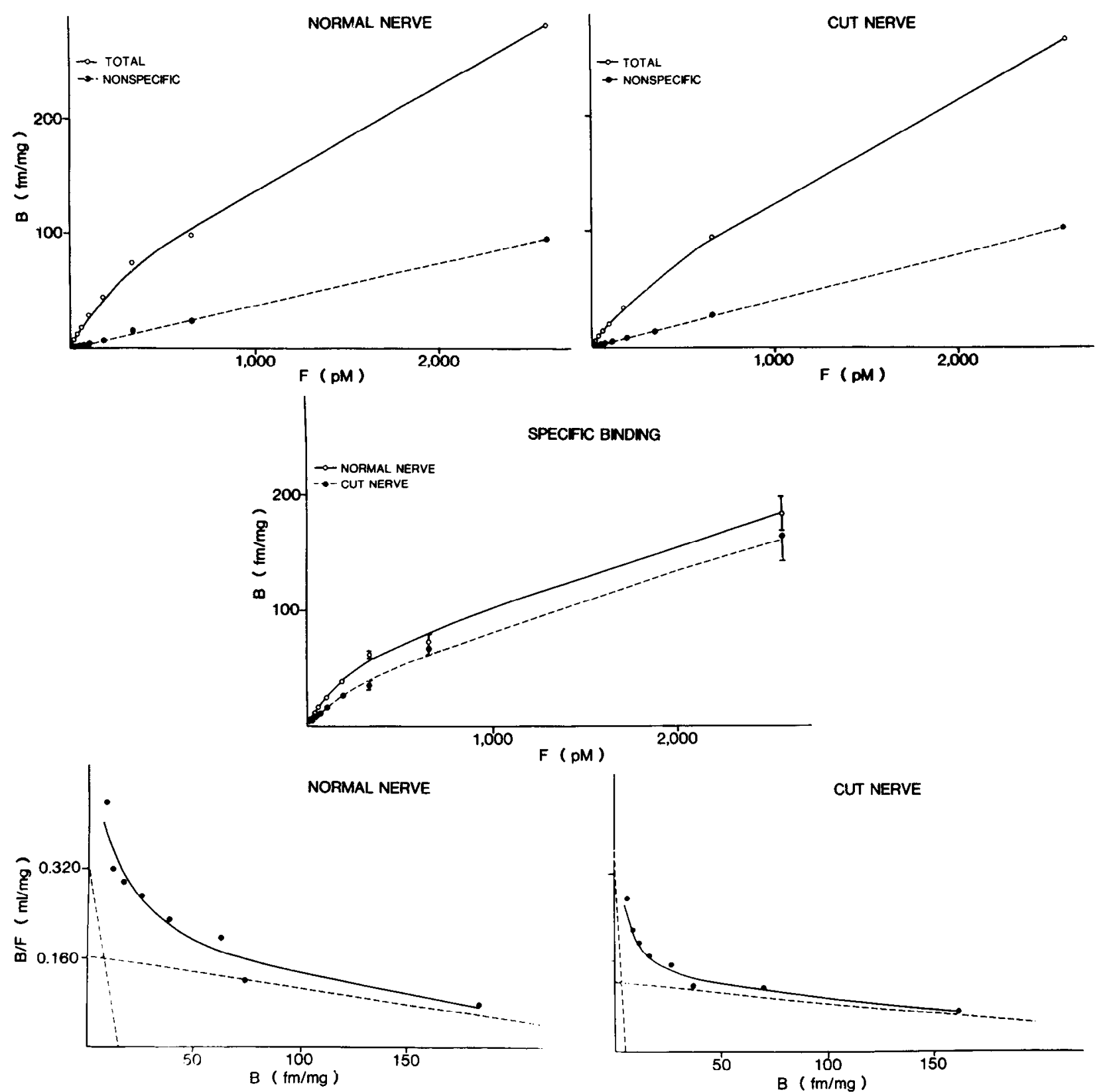

SPECFIC BNDNG 


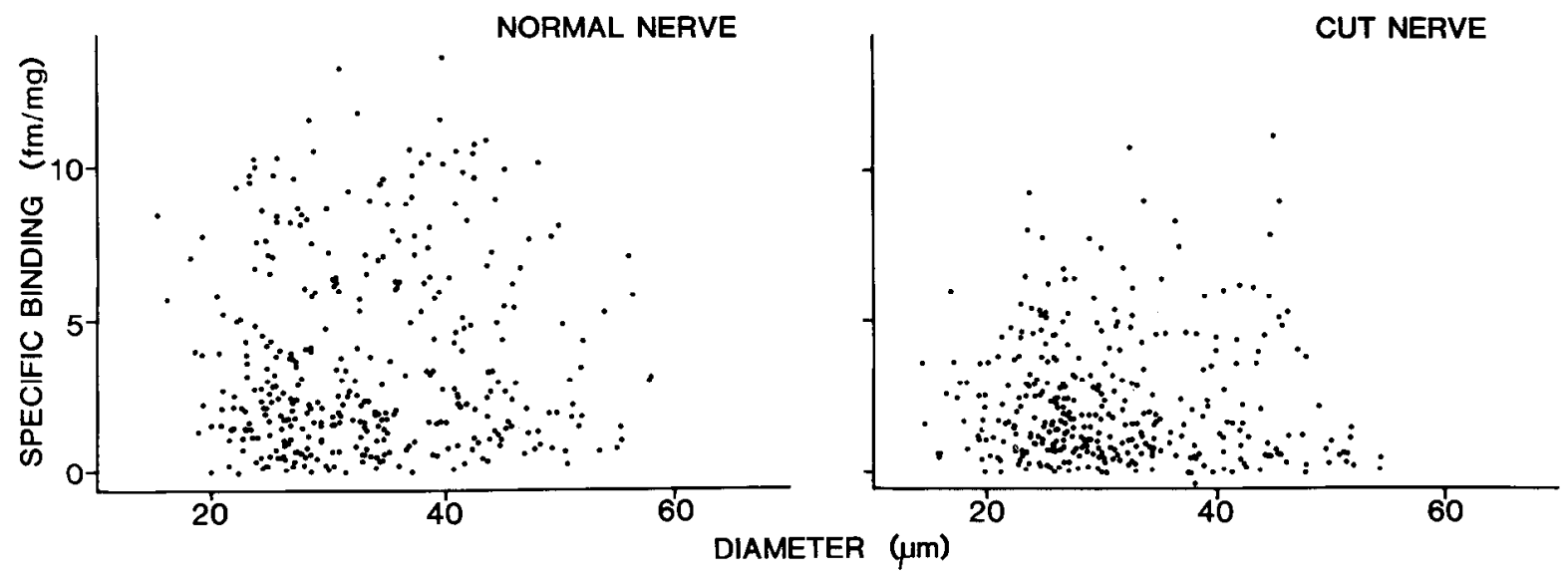

LARGE
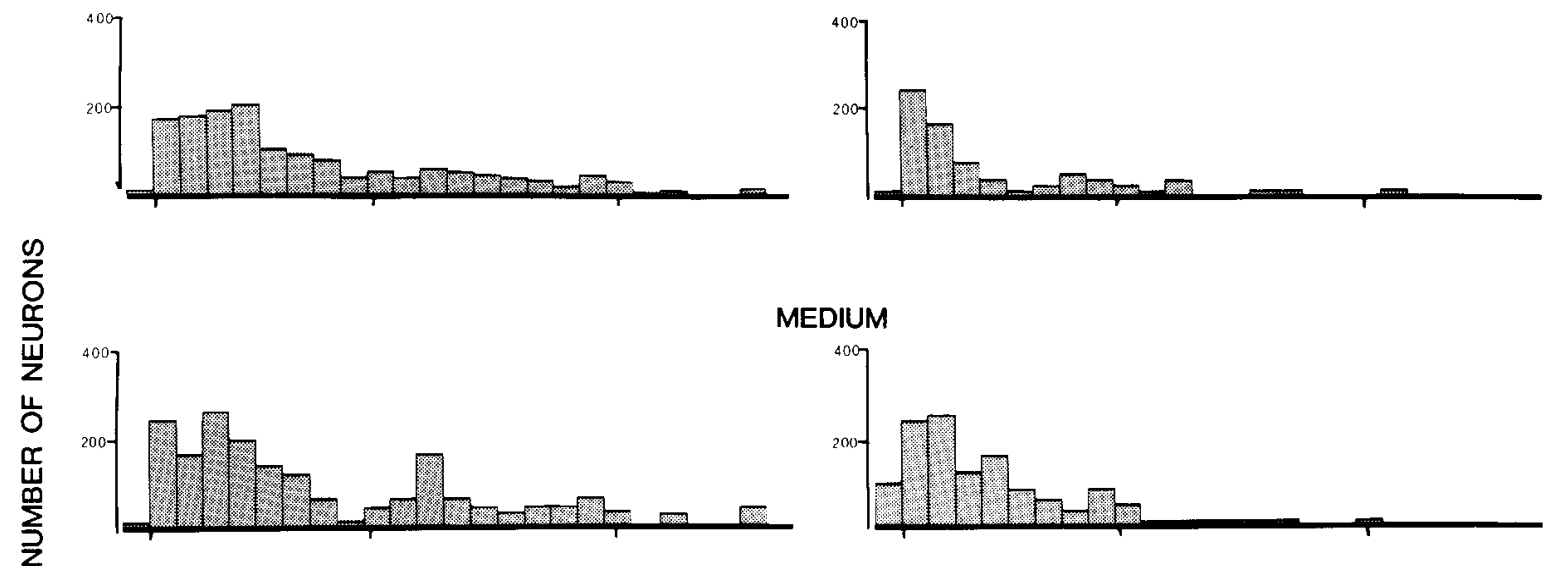

MEDIUM
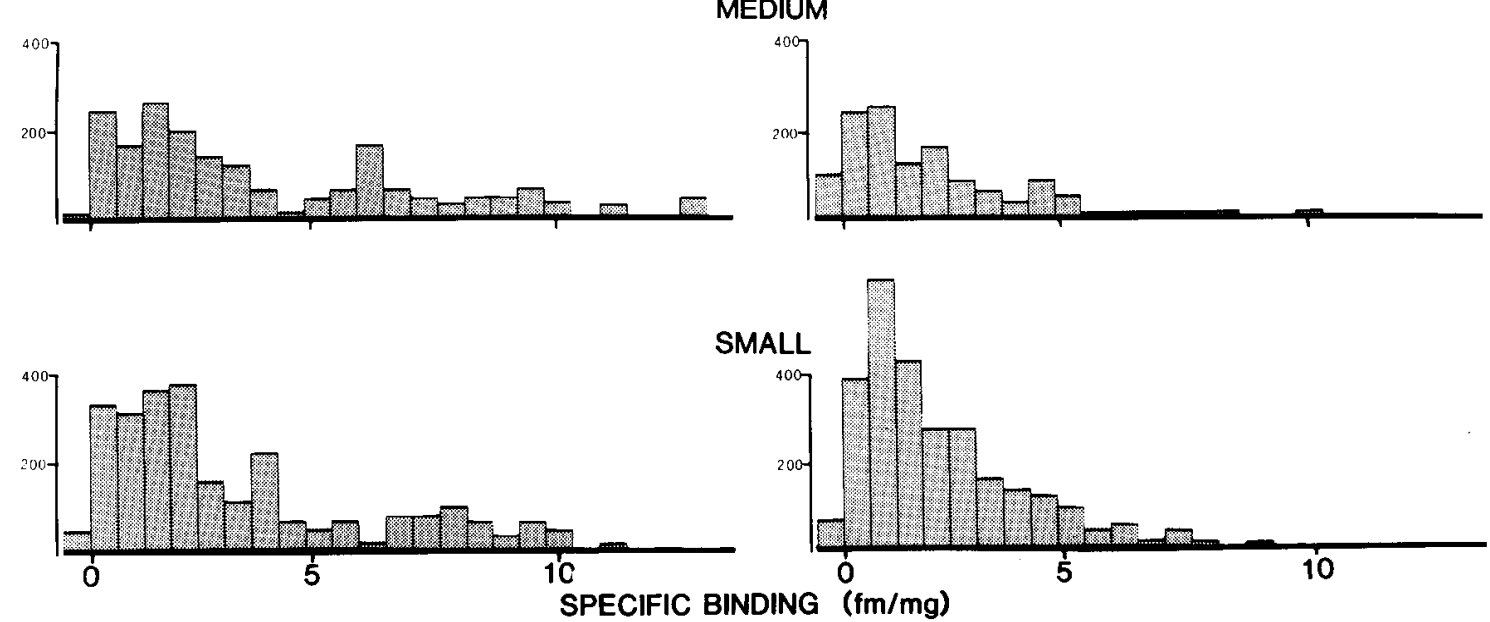

Figure 3. Data from NGF-receptor radioautographs for the same pairs of L5 DRG as in Figure 2. Top, Scatter diagrams in which each point represents a single neuron $(n=400)$. In the normal DRG, clusters of neurons with dense and light labeling are separable for large neurons but merge for small neurons. Note that binding and size both tend to decrease following nerve injury. Below, Neurons were classified as small $(<30$ $\mu \mathrm{m})$, medium $(30-40 \mu \mathrm{m})$, or large $(>40 \mu \mathrm{m})$, and histograms of binding densities were prepared for each population. After nerve injury, very few of the large or medium neurons have labeling more than 5 times background. The absolute number of small lightly labeled neurons is increased.

counteracted atrophy and decreased labeling for the former but not the latter group (Table 2). In summary, delayed infusion of NGF substantially reverses the atrophy and reduction in receptor density that follow sciatic nerve transection.

\section{Retrograde transport studies}

Uptake of ${ }^{125} \mathrm{I}-\mathrm{NGF}$ from crushed and normal sciatic nerves did not differ significantly at any of the 3 times after injury (Fig. 6).

Ten days after cutting of the sciatic nerve, the maximal accumulation of ${ }^{125}$ I-NGF in L5 DRG following intraneural injection was calculated to fall from 29 to $18 \mathrm{pg}$ (Fig. 7). Because very little NGF would be expected to diffuse to midthigh after intraneural injection at the hip (Richardson and Riopelle, 1984), the effective length of nerve exposed to ${ }^{125} \mathrm{I}-\mathrm{NGF}$ should be the same for cut and normal nerves. Therefore, the reduced uptake indicates fewer receptor-bearing axons and/or fewer receptors per unit length of axon.

\section{Discussion}

$N G F$ receptors on normal sensory neurons

The binding sites within neuronal perikarya are here called receptors even though most of them are not inserted in the cell membrane and are therefore not in position to interact with endogenous NGF. It is assumed that most perikaryal receptors 
NORMAL NERVE
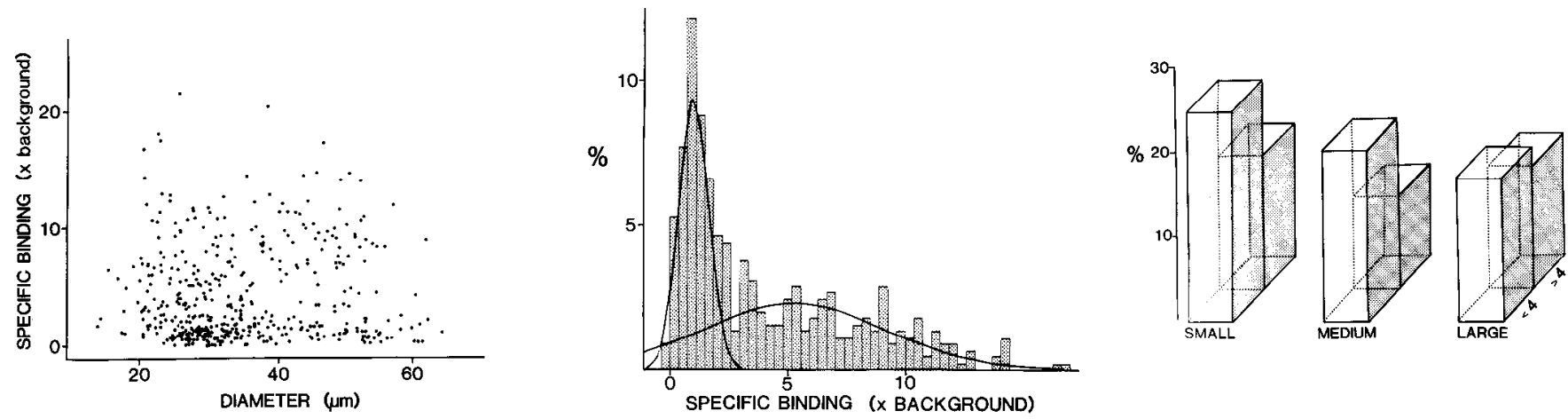

\section{CUT NERVE}
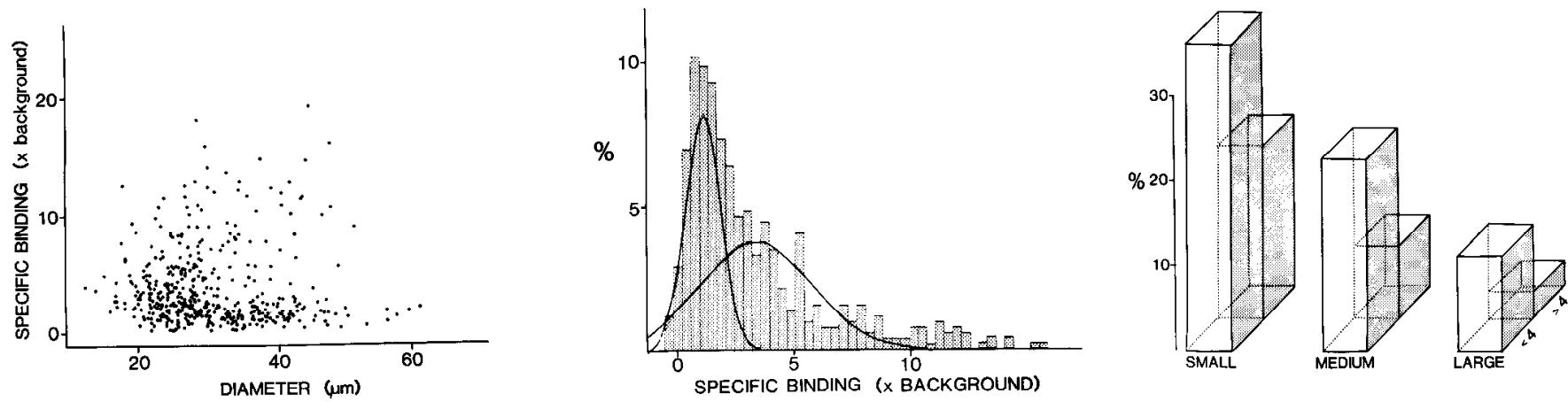

\section{CUT NERVE + NGF}
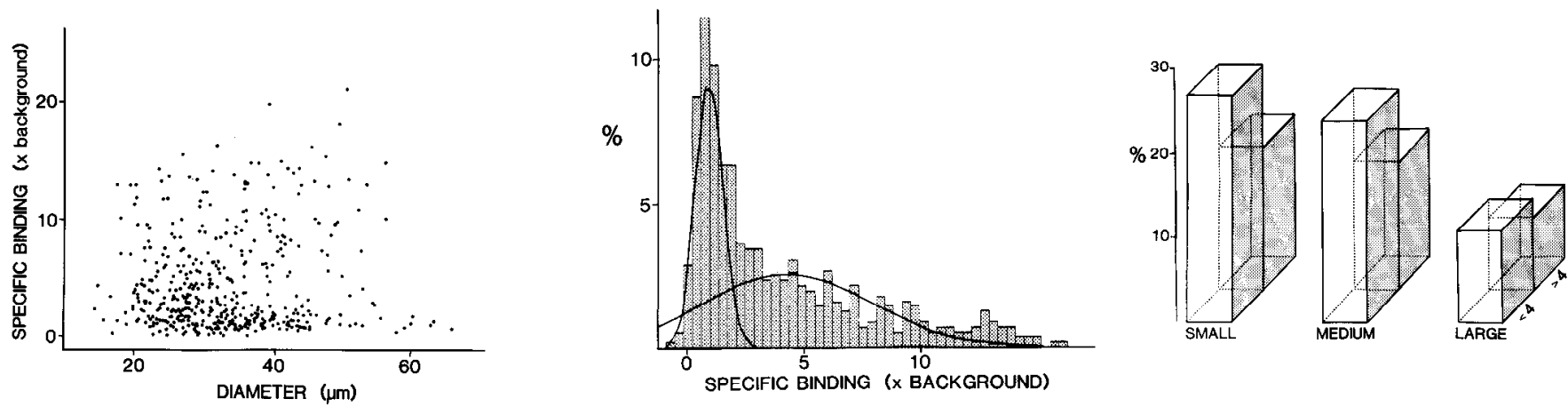

Figure 4. Quantitative data for radioautographs of 3 groups of DRG in which the sciatic nerve was either intact, cut, or cut and later infused with NGF. In the scatter diagrams (left), specific binding is expressed relative to nonspecific binding over non-neuronal areas of normal ganglia. Note the diminution of neuronal size and ${ }^{125}$ I-NGF labeling following nerve cut with partial restoration by infusion of NGF $(n=448)$. Histograms of the density of binding (middle) were fitted to 2 normal curves by a maximum likelihood programme (Lawson, 1979). The 3 "labeled" populations constituted $60-64 \%$ of neurons and had binding densities of $5.4 \pm 0.4,3.6 \pm 0.2$, and $4.6 \pm 0.3$ times background for the normal, cut, and NGF groups (means \pm SEM, $n=448-548$ ). Right, neurons are classified as small, medium, or large with diameters $<30 \mu \mathrm{m}, 30-40 \mu \mathrm{m}$, and $>40 \mu \mathrm{m}$, respectively, and also subdivided into those with specific binding less or greater than 4 times nonspecific binding. The latter partition seems appropriate at least for large neurons in normal ganglia. Notice that the bin for large heavily labeled neurons is very small following nerve transection and increases after NGF infusion.

are newly synthesized and awaiting anterograde transport, although some may have been retrogradely transported with their ligand (Raivich and Kreutzberg, 1987).

For radioautographs of normal L5 DRG, histograms of neuronal labeling densities are bimodal, fitting 2 normal curves and suggesting the existence of 2 populations of sensory neurons. Scatchard analysis of the concentration dependence of binding shows that heavily labeled neurons have saturable binding with dissociation-equilibrium constant of 15-50 pM plus additional binding of lower affinity. For lightly labeled neurons, Scatchard 
Figure 5. Radioautography of the spinal cord at L5 root entry level in a rat sacrificed 7 weeks after transection of the right sciatic nerve. The dorsal spinal roots are outlined. NGF binding to fibers in the superficial dorsal horn is diminished on the right side compared with the normal left side. Also, abnormal speckled binding is seen within the right L5 dorsal spinal root, presumably NGF receptors expressed by Schwann cells associated with degenerated central processes ([125-NGF] $=50 \mathrm{pm}) . \times 40$.

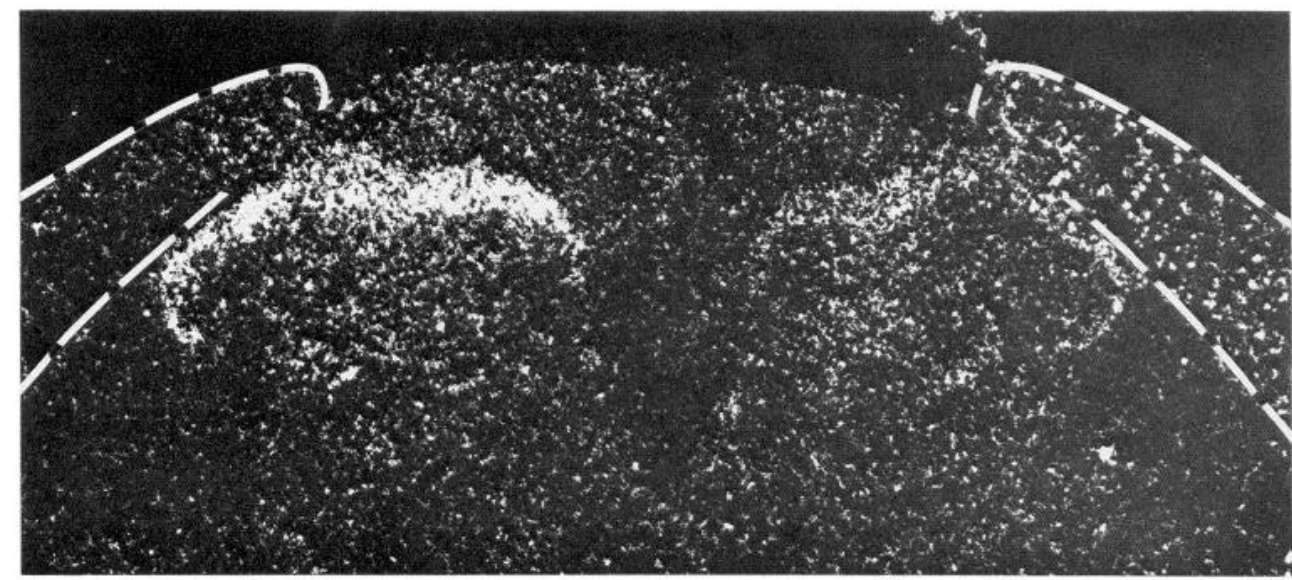

analysis indicates an absence or very small number of highaffinity receptors. Several tissue culture and retrograde transport studies also suggest that significant numbers of rat and chick DRG neurons are unresponsive to NGF at physiological concentration (Richardson and Riopelle, 1984; Davies and Lindsay, 1985; Davies et al., 1986). For lumbar DRG in adult rats, approximately half of the sensory neurons have high-affinity NGF receptors. This population of NGF-responsive sensory neurons has not been described in terms of function and other markers (Dodd et al., 1983).

Because of technical considerations, no conclusions have been drawn from the radioautographs regarding low-affinity receptors. For picomolar concentrations of radioligand, only a small percentage of low-affinity sites should be occupied, and this binding should be displaced after washing for $3 \mathrm{~min}$ (Sutter et al., 1979). The persistence of low-affinity binding under the conditions for radioautography could indicate nonphysiological sequestration of NGF by intracellular receptors artificially exposed to NGF. Nevertheless, low-affinity binding can and must be taken into account to obtain accurate values for the functionally important high-affinity receptor.

\section{Regulation of the NGF receptor}

Following peripheral nerve injury, the number of high-affinity receptors on some sensory neurons falls by more than $80 \%$ through a combination of atrophy and reduced density. This disappearance of perikaryal NGF receptors after nerve injury does not merely reflect translocation from cell body to axon because the receptors on peripheral and central axons are also decreased. The receptor loss is not a simple consequence of

Table 1. Changes in perikaryal volume after nerve injury

\begin{tabular}{lll}
$\begin{array}{l}\text { Days after } \\
\text { nerve cut }\end{array}$ & $\begin{array}{l}\text { Lightly labeled } \\
\text { neurons }\end{array}$ & $\begin{array}{l}\text { Heavily labeled } \\
\text { neurons }\end{array}$ \\
\hline 18 & $0.85(32.6 / 38.5)$ & $0.67(20.9 / 31.2)$ \\
18 & $0.97(22.2 / 22.9)$ & $0.72(18.2 / 25.3)$ \\
30 & $0.73(23.1 / 31.6)$ & $0.54(15.7 / 29.1)$ \\
39 & $0.77(23.9 / 31.0)$ & $0.54(15.1 / 28.2)$
\end{tabular}

For this table, the most heavily and lightly labeled thirds of the neuronal population were selected from each group. The values for DRG associated with cut sciatic nerves are expressed as fractions of the values for control DRG. Atrophy is consistently more severe for heavily than lightly labeled neurons. (Volumes/10 in $\mu \mathrm{m}^{3}$, means \pm SEM, $n=80-179$ ). selective neuronal death because it is reversed by delayed administration of NGF. Finally, the injury-induced loss of highaffinity NGF receptors exceeds any general reduction in ganglionic proteins or axonally transported proteins (Perry and Wilson, 1981). In response to peripheral nerve injury, either highaffinity receptors are selectively down-regulated or neurons with such receptors are exceptionally perturbed.

The molecular mechanisms leading to a reduction in highaffinity NGF receptors are unknown. In the absence of a reliable cDNA probe for the high-affinity receptor, the defect cannot be defined as translational or posttranslational. Perhaps, the NGF receptor is co-regulated with substance $\mathbf{P}$ and neurofilament, which are also reduced in injured sensory neurons (Tessler et al., 1985; Hoffman et al., 1987) and induced by NGF (Goedert et al., 1981; Fitzgerald et al., 1985; Dickson et al., 1986). Because several neuronal receptors are down-regulated in response to axonal injury (Rotter et al., 1977; Fumagalli and de Renzis, 1980; Helke et al., 1984), the change in NGF receptors might reflect a general impairment in receptor preparation (Goldberg and Ambron, 1986). The different responses to nerve injury of high-affinity neuronal receptors and low-affinity Schwann cell receptors (Raivich and Kreutzberg, 1987; Taniuchi et al., 1988) attest to some complexity in the regulation of NGF receptors.

Infusion of NGF restores high-affinity sites that disappear on neurons with cut axons. This evidence that NGF can regulate its functional high-affinity receptor in adult mammalian neurons corroborates previous studies in pheochromocytoma cells (Landreth and Shooter, 1980; Bernd and Greene, 1984). The general

Table 2. Recovery of size and binding sites following administration of NGF to the cut sciatic nerve

\begin{tabular}{llllll} 
& Volume & & & Labeling \\
\cline { 2 - 3 } \cline { 5 - 6 } Sciatic nerve & $\begin{array}{l}\text { Lightly } \\
\text { labeled }\end{array}$ & $\begin{array}{l}\text { Heavily } \\
\text { labeled }\end{array}$ & & $\begin{array}{l}\text { Lightly } \\
\text { labeled }\end{array}$ & $\begin{array}{l}\text { Heavily } \\
\text { labeled }\end{array}$ \\
\hline Normal & $31.6 \pm 2.4$ & $29.1 \pm 1.9$ & $0.6 \pm 0.03$ & $8.4 \pm 0.2$ \\
Cut & $23.1 \pm 1.4$ & $15.7 \pm 0.9$ & $0.7 \pm 0.03$ & $6.9 \pm 0.3$ \\
NGF-treated & $25.0 \pm 1.8$ & $24.0 \pm 1.8$ & $0.6 \pm 0.03$ & $8.9 \pm 0.3$
\end{tabular}

The most lightly and heavily labeled thirds of the neuronal population were analyzed separately. NGF pumps were inserted $21 \mathrm{~d}$ after cutting of the sciatic nerve and rats were killed after a further $9 \mathrm{~d}$. Note that NGF significantly counteracts the effects of nerve cutting for the heavily labeled group only $(p<0.0001$ by the Student's $t$ test for both labeling and volume). Specific labeling is expressed as a ratio of nonspecific labeling for normal ganglia. (Volumes $/ 10^{3}$ in $\mu \mathrm{m}^{3}$, means \pm SEM, $n=145-180$.) 


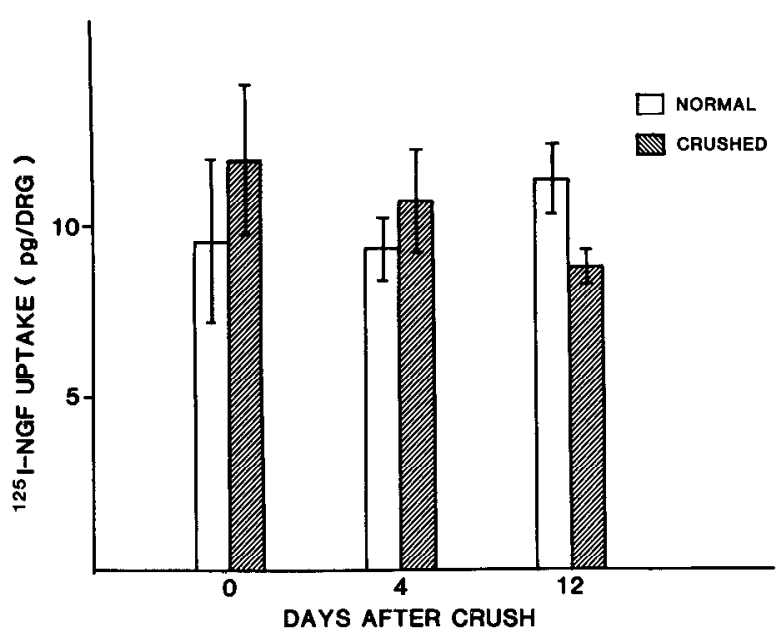

Figure 6. Accumulation of ${ }^{125} \mathrm{I}-\mathrm{NGF}$ in L4 and L5 DRG $12 \mathrm{hr}$ after injection $(1 \mu \mathrm{l}, 11 \mathrm{ng})$ into normal sciatic nerve or nerve that had been crushed 0-12 d earlier (means \pm SEM, $n=4-5$ for each point).

concept that growth factors induce synthesis of their own receptors receives support from studies of epidermal growth factor (Carpenter, 1987) and interleukin-2 (Waldmann, 1986).

\section{Neuronal responses to injury}

Sensory neurons with high-affinity NGF receptors are selectively vulnerable to atrophy following peripheral nerve injury (Table 2). However, lack of NGF is not the only cause of neuronal atrophy because NGF fails to restore cell volume completely (Table 2; Rich et al., 1987). These and other neuronal counts (Arvidsson et al., 1986) suggest that approximately $20 \%$ of the neurons in rat I.5 DRG have died 1 month after sciatic nerve transection. Although some sensory neurons indubitably die after peripheral nerve injury (Aldskogius et al., 1985), neuronal death could be overestimated in cryostat sections, where shrunken neurons can become difficult to identify. For cholinergic forebrain neurons (Hagg et al., 1988) and sensory neurons, biochemical and morphological changes that can mimic neuronal death are reversible by delayed infusion of NGF.

The changes in neuronal NGF receptors following peripheral nerve injury are clearly degenerative rather than regenerative. The data provide no suggestion of a supersensitivity to NGF that might contribute to the regenerative propensity of injured sensory neurons (Richardson and Issa, 1984; Richardson and Verge, 1987). Rather, regressive changes are probably accentuated by the diminution of NGF binding, possibly through a vicious cycle with reduction in perikaryal NGF and decreased receptor synthesis. These and other findings suggest that some degenerative changes in injured sensory neurons are caused by a reduction in retrograde axonal transport of NGF: such responses are mitigated by exogenous NGF and presumably by NGF in the distal stump (Heumann et al., 1987) of a crushed or sutured nerve.

\section{References}

Aldskogius, H., J. Arvidsson, and G. Grant (1985) The reaction of primary sensory neurons to peripheral nerve injury with particular emphasis on transganglionic changes. Brain Res. Rev. 10: 27-46.

Arvidsson, J., J. Ygge, and G. Grant (1986) Cell loss in lumbar dorsal root ganglia and transganglionic degeneration after sciatic nerve resection in the rat. Brain Res. 373: 15-21.

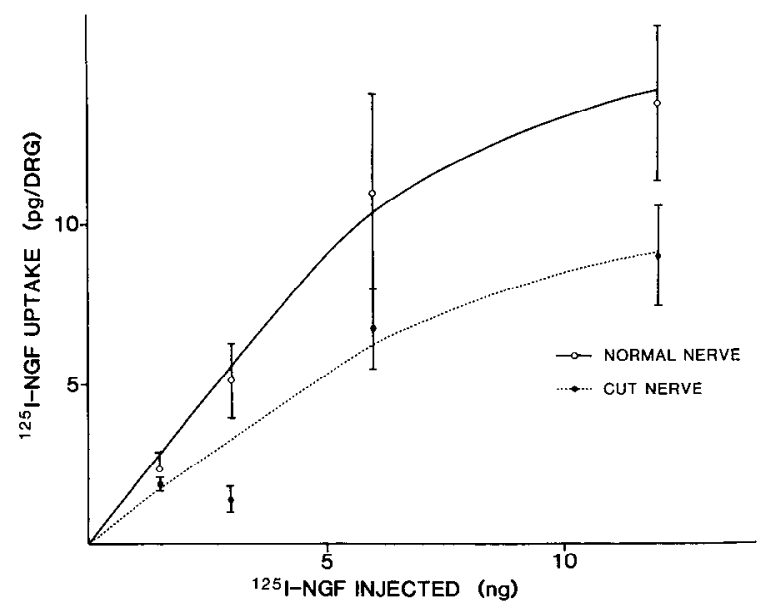

Figure 7. Accumulation of ${ }^{125}$ I-NGF in L4 and L5 DRG $18 \mathrm{hr}$ after injection into normal sciatic nerve or nerve transected 9-10 d earlier $(n=7-10$ for each point).

Barlow, R. B. (1983) Biodata Handling with Microcomputers, Elsevier, New York.

Bernd, P., and L. A. Greene (1984) Association of ${ }^{125}$ I-nerve growth factor with PC12 pheochromocytoma cells. J. Biol. Chem. 259: 1550915516.

Carpenter, G. (1987) Receptors for epidermal growth factor and other polypeptide mitogens. Annu. Rev. Biochem. 56: 881-914.

Chandler, C. E., L. M. Parsons, M. Hosang, and E. M. Shooter (1984) A monoclonal antibody modulates the interaction of nerve growth factor with PC12 cells. J. Biol. Chem. 259: 6882-6889.

Chapman, C. A., B. E. C. Banks, C. A. Vernon, and J. M. Walker (1981) The isolation and characterisation of nerve growth factor from the prostate gland of the guinea-pig. Eur. J. Biochem. 115: 347-351.

Davies, A. M., and R. M. Lindsay (1985) The cranial sensory ganglia in culture. Dev. Biol. 111: 62-72.

Davies A. M., H. Thoenen, and Y.-A. Barde (1986) The response of chick sensory neurons to brain-derived neurotrophic factor. J. Neurosci. 67: 1897-1904.

Dickson, G., H. Prentice, J.-P. Julien, G. Ferrari, A. Leon, and F. S. Walsh (1986) Nerve growth factor activates Thy-1 and neurofilament gene transcription in rat PC12 cells. EMBO J. 5: 3449-3453.

Dodd, J., C. E. Jahr, P. N. Hamilton, M. J. S. Heath, W. D. Mathew, and T. M. Jessell (1983) Cytochemical and physiological properties of sensory and dorsal horn neurons that transmit cutaneous sensation. Cold Spring Harbor Symp. Quant. Biol. 48: 685-695.

Fitzgerald, M., P. D. Wall, M. Goedert, and P. C. Emson (1985) Nerve growth factor counteracts the neurophysiological and neurochemical effects of chronic sciatic nerve section. Brain Res. 332: 131-141.

Fumagalli, L., and G. de Renzis (1980) $\alpha$-Bungarotoxin binding sites in the rat superior cervical ganglion are influenced by postganglionic axotomy. Neuroscience 5: 611-616.

Goedert, M., K. Stoeckel, and U. Otten (1981) Biological importance of the retrograde axonal transport of nerve growth factor in sensory neurons. Proc. Natl. Acad. Sci. USA 78: 5895-5898.

Goldberg, D. J., and R. T. Ambron (1986) Consequences of partial axotomy for production of neurotransmitter vesicles and routing of rapidly transported membrane glycoproteins in the axonal tree. $\mathbf{J}$. Neurosci. 6: 1712-1718.

Green, S. H., and L. A. Greene (1986) A single $\mathrm{Mr}=103,000^{125} \mathrm{I}-\beta$ nerve growth factor-affinity-labeled species represents both the low and high affinity forms of the nerve growth factor receptor. J. Biol. Chem. 261: 15316-15326.

Hagg, T., M. Manthorpe, H. L. Vahlsing, and S. Varon (1988) Delayed treatment with nerve growth factor reverses the apparent loss of cholinergic neurons after acute brain damage. Exp. Neurol. 101: $303-$ 312.

Helke, C. J., C. W. Shults, T. N. Chase, and T. L. O'Donohue (1984) Autoradiographic localization of substance $P$ receptors in rat medulla: Effect of vagotomy and nodose ganglionectomy. Neuroscience 12 : 215-223. 
Heuer, J. G., G. C. Schatteman, and M. Bothwell (1987) Localization of NGF receptor mRNA and protein in primate sensory neurons. Soc. Neurosci. Abstr. 13: 517.

Heumann, R., S. Korsching, C. Bandtlow, and H. Thoenen (1987) Changes of nerve growth factor synthesis in nonneuronal cells in response to sciatic nerve transection. J. Cell Biol. 104: 1623-1631.

Hoffman, P. N., D. W. Cleveland, J. W. Griffin, P. W. Landes, N. J. Cowan, and D. L. Price (1987) Neurofilament gene expression: A major determinant of axonal caliber. Proc. Natl. Acad. Sci. USA 84 : 3472-3476.

Hosang, M., and E. M. Shooter (1985) Molecular characteristics of nerve growth factor receptors on PC12 cells. J. Biol. Chem. 260:655662.

Johnson, D., A. Lanahan, C. R. Buck, A. Sehgal, C. Morgan, E. Mercer, M. Bothwell, and M. Chao (1986) Expression and structure of the human NGF receptor. Cell 47: 545-554.

Johnson E. M., K. M. Rich, and H. K. Yip (1986) The role of NGF in sensory neurons in vivo. TINS 9: 33-37.

Landreth, G. E., and E. M. Shooter (1980) Nerve growth factor receptors on PC12 cells. Proc. Natl. Acad. Sci. USA 77: 4751-4755.

Lawson, S. N. (1979) The postnatal development of large light and small dark neurons in mouse dorsal root ganglia: A statistical analysis of cell numbers and size. J. Neurocytol. 8: 275-294.

McQuarrie, I. G., B. Grafstein, and M. D. Gershon (1977) Axonal regeneration in the rat sciatic nerve: Effect of a conditioning lesion and of dbcAMP. Brain Res. 132: 443-453.

Minneman, K. P., L. R. Hegstrand, and P. B. Molinoff (1979) Simultaneous determination of beta- 1 and beta-2-adrenergic receptors in tissues containing both receptor subtypes. Mol. Pharmacol. 16:3446.

Mobley, W. C., A. Schenker, and E. M. Shooter (1976) Characterization and isolation of proteolytically modified nerve growth factor. Biochemistry 15: 5543-5551.

Perry, G. W., and D. L. Wilson (1981) Protein synthesis and axonal transport during nerve regeneration. J. Neurochem. 37: 1203-1217.

Radeke, M. J., T. P. Misko, C. Hsu, L. A. Herzenberg, and E. M. Shooter (1987) Gene transfer and molecular cloning of the rat nerve growth factor receptor. Nature 325: 593-597.

Raivich, G., and G.W. Kreutzberg (1987) Expression of growth factor receptors in injured nervous tissue. J. Neurocytol. 16: 689-700.

Rich, K. M., J. R. Luszczynski, P. A. Osborne, and E. M. Johnson, Jr. (1987) Nerve growth factor protects adult sensory neurons from cell death and atrophy caused by nerve injury. J. Neurocytol. 16:261268.

Richardson, P. M., and V. M. K. Issa (1984) Peripheral injury enhances central regeneration of primary sensory neurons. Nature 309 : 791-793.

Richardson, P. M., and R. J. Riopelle (1984) Uptake of nerve growth factor along peripheral and spinal axons of primary sensory neurons. J. Neurosci. 4: 1683-1689.

Richardson, P. M., and V. M. K. Verge (1987) Axonal regeneration in dorsal spinal roots is accelerated by peripheral axonal transection. Brain Res. 411: 406-408.

Richardson, P. M., V. M. K. Verge Issa, and R. J. Riopelle (1986) Distribution of neuronal receptors for nerve growth factor in the rat. J. Neurosci. 6: 2312-2321.

Richardson, P. M., V. M. K. Verge, and R. J. Riopelle (1988) Quantitative radioautography for NGF receptors. In Nerve Growth Factors, R. A. Rush, ed., pp. 315-326, Wiley, New York.

Robb, R. J., and Greene, W. C. (1987) Internalization of interleukin 2 is mediated by the $\beta$ chain of the high-affinity interleukin 2 receptor. J. Exp. Med. 165: 1201-1206.

Ross, A. H., P. Grob, M. Bothwell, D. E. Elder, C. S. Ernst, N. Marano, B. F. D. Ghrist, C. C. Slemp, M. Herlyn, B. Atkinson, and H. Koprowski (1984) Characterization of nerve growth factor receptor in neural crest tumors using monoclonal antibodies. Proc. Natl. Acad. Sci. USA 81: 6681-6685.

Rotter, A., N. J. M. Birdsall, A. S. V. Burgen, P. M. Field, and G. Raisman (1977) Axotomy causes loss of muscarinic receptors and loss of synaptic contacts in the hypoglossal nucleus. Nature 266:734735.

Sutter, A., R. J. Riopelle, R. M. Harris-Warrick, and E. M. Shooter (1979) Nerve growth factor receptors. J. Biol. Chem. 254: 59725982.

Taniuchi, M., H. B. Clark, J. B. Schweitzer, and E. M. Johnson (1988) Expression of nerve growth factor receptors by Schwann cells of axotomized peripheral nerves. J. Neurosci. 8: 664-681.

Tessler, A., B. T. Himes, N. R. Krieger, M. Murray, and M. E. Goldberger (1985) Sciatic nerve transection produces death of dorsal root ganglion cells and reversible loss of substance $\mathbf{P}$ in spinal cord. Brain Res. 332: 209-218.

Waldmann, T. A. (1986) The structure, function, and expression of interleukin-2 receptors on normal and malignant lymphocytes. Science 232: 727-732. 